\title{
ANALYSIS OF PERFORMANCE OF TIMBER HARVESTING WITH THE USE OF HIGHLANDER HARVESTER
}

\author{
Mariusz Kormanek*, Mariusz Kępa \\ Department of Forest Work Mechanisation, University of Agriculture in Krakow \\ *Corresponding author: e-mail: rlkorma@cyf-kr.edu.pl
}

\begin{tabular}{|c|c|}
\hline ARTICLE INFO & ABSTRACT \\
\hline $\begin{array}{l}\text { Article history: } \\
\text { Received: January } 2016 \\
\text { Received in the revised form: } \\
\text { March } 2016 \\
\text { Accepted: April } 2016\end{array}$ & \multirow{2}{*}{$\begin{array}{l}\text { The paper presents the work performance analysis of timber harvest- } \\
\text { ing with the use of Highlander harvester produced by KONRAD } \\
\text { Forsttechnik GmbH. The analysis was performed based on the timing } \\
\text { of the working day. We also assessed the organization of the machine } \\
\text { operation in the research area and its functional capability. The study } \\
\text { was conducted in Międzylesie Forest Department, Nowa Wies Forest- } \\
\text { ry in fresh mixed mountain forest, where the machine acquired spruce. } \\
\text { Timing was performed based on the registration of the machine opera- } \\
\text { tion on a video camera and the measurements of collected assortment. } \\
\text { Based on the results of measurements it was found that organization of } \\
\text { the machine operation was not the best. A one-shift work system and } \\
\text { short duration of a shift caused that the effective working time occu- } \\
\text { pied only } 67.9 \% \text { of the shift time (about } 4 \text { hours). This resulted in } \\
\text { reduction of the operating performance on a working day which was } \\
\text { only } 12.7 \mathrm{~m}^{3} \cdot \mathrm{h}^{-1} \text {, while an effective high-efficiency was } 18.7 \mathrm{~m}^{3} \cdot \mathrm{h}^{-1} \text {. }\end{array}$} \\
\hline $\begin{array}{l}\text { Key words: } \\
\text { timber harvesting, } \\
\text { work performance, } \\
\text { harvester }\end{array}$ & \\
\hline
\end{tabular}

\section{Introduction}

Machinery logging is understood as an operation in which an operator has no direct contact with an object of production. Today, t mechanization of harvesting is made by highperformance machines, mainly by harvesters and forwarders (Moskalik, 2002). First harvesters in Poland appeared in the late 80s of the twentieth century, and in 1996 the State Forests purchased two first machines for the two forest districts (Bodył, 2014). In 2001 it was 10 harvesting machines, and 67 in 2006 (Skarżyński and Brzózko, 2010). The largest increase in the number of machines occurred in 2006 -2008, when the number of harvesters in private hands grew to more than 120 pieces. Later, there was a significant slowdown of the growth resulting from the global economic crisis, which also affected the size of wood demand in Poland. In 2011 it was 485 forwarders and 351 harvesters, and currently, it is estimated that in Poland more than 600 forwarders and about 300 harvesters operate (Information RDLP, 2010; Skarżyński and Brzózko, 2010). It proves a high potential of forestry clients and strong market pressure related to a low number of people who would work hard in state forests (Information RDLP; Żabierek, 2013). A significant number of high performance machines of the forwarder and harvester type in Poland are owned by private companies which provide services to forestry, and especially for the State Forests. Harvest- 
ers working in Poland are mainly machines produced by John Deere, Ponsse and Valmet, with a combined market share of over 84\%, with the largest share of John Deere - 37\% (Information RDLP, 2010). Under Polish conditions, mechanical harvesting of timber begins from early thinning and ends with the harvest cutting. To apply a harvester on a given utilized area several factors should be taken into account: a diameter of the sheared trees, the number of trees per hectare, terrain and distance between trees. Hence the manufacturers in their trade offer have usually several models of different sizes and specifications. The various models differ with weight, engine power, chassis, outreach crane and a maximum cutting diameter (Skarżyński and Brzózko, 2010). Moreover, since 2012 in the Polish forests also a very interesting innovative harvester works. Undoubtedly it is a Highlander harvester produced by KONRAD Forsttechnic GmbH. It was acquired by a private owner from the south-west of Poland. The harvester works in difficult mountain conditions, but also in less extreme conditions if there is an urgent need. The objective of the study was to determine the balance of the working time of the Highlander type machine based on the timing of the working day and the characteristic of selected properties of the harvester.

\section{Material and Methods}

The study was conducted in Międzylesie Forestry District, Forestry Nowa Wieś, section 59d. The study area was located in an economy forest stand, age of trees -47 years, forestation rate -0.9 , condensation - moderate intermittent, an area with little inclination of approximately $1 \mathrm{~m}$ to $100 \mathrm{~m}$, a forest type - a fresh mixed mountain forest, variant of moisture - strongly fresh, natural habitat status. The tree stand was primarily spruce, beech and sycamore. The soil type was podsoil, soil strongly turfed. On the research area 10 seats were carried, and the cut-out was partly necessitated by damage from caps of snow. The work was carried out with Highlander harvester equipped with Woody 60 harvester head (fig. 1). Woody 60 harvesting head is designed for timber cutting and processing and it may be used as a loading gripper. The unique and patented design allows processing of both deciduous and bent or broken conifers (Information materials of KONRAD Forsttechnic $\mathrm{GmbH}$ ). The Wood head may be mounted on a harvester, forwarder and also on an excavator (Information materials of KONRAD Forsttechnic GmbH). The harvester is also equipped with indispensable devices such as: the measurement system with control, lighting for the front and back of the cabin, video camera , winch with a control pilot and a clambank may be additionally installed. Table 1 presents the basic technical data of the harvester and head. The harvester during the tests performed felling, delimbing and cut to length, while a sophisticated assortment was logged with Belarus 1025 tractor equipped with an $81 \mathrm{~kW}$ engine (http://lupus-wilk.com.pl) and Fao-Far FF942 logging trailer with a capacity of $9 \mathrm{t}$ equipped with a Fao-Far 3264 crane with a range of $6.4 \mathrm{~m}$ and the lifting moment of $32 \mathrm{kNm}$ (http://www.faofar.pl). Determination of the individual components of the balance of the machine working time in operation is based on the timing of the working day. 


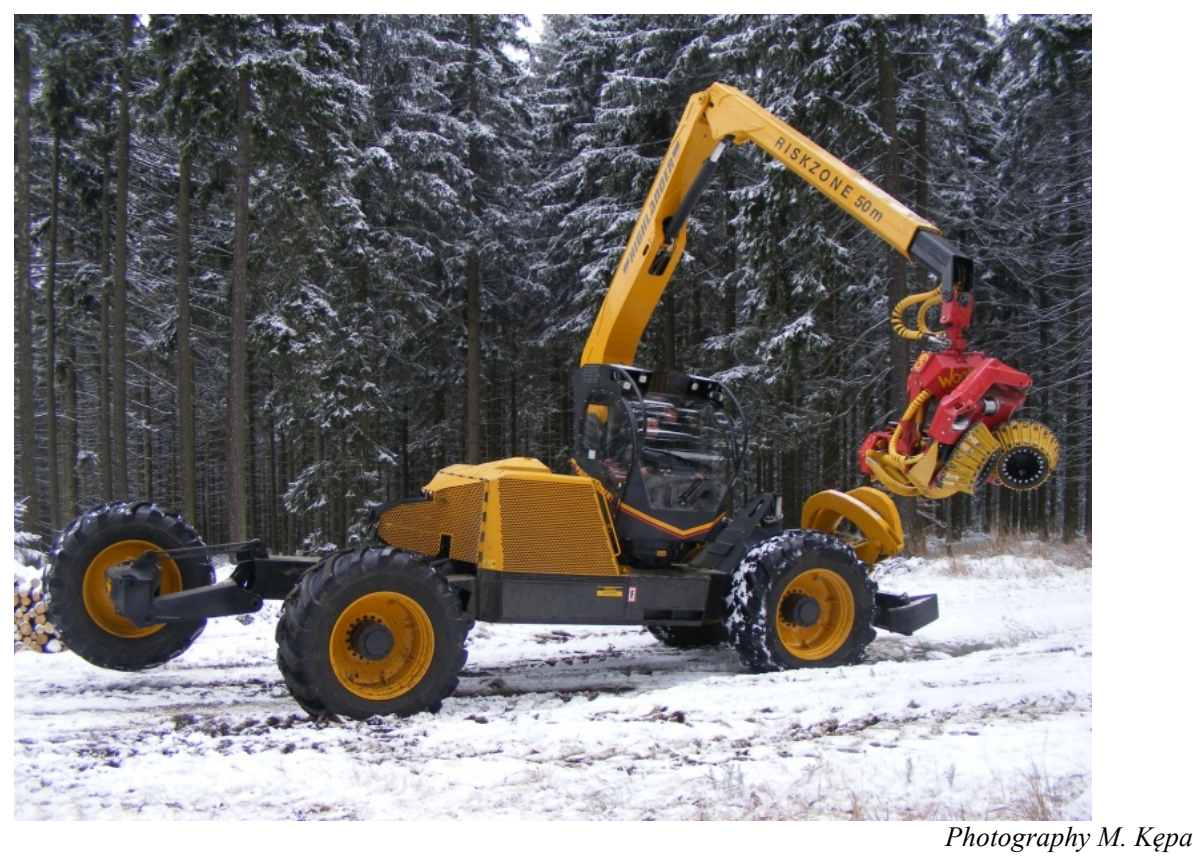

Figure 1. Highlander harvester

Time measurement and video recording in a working day consisted of measuring with a stopwatch the time needed to reach and return from the work area and video recording of the machine from the moment it reached the workplace. The total video recording time was 6 hours and contained 75 complete cycles of tree treatment such as felling, delimbing and cut to length. Video recording was carried out with the use of JVC GZ-MG camera. The terms of volume of treated trees was based on measuring a diameter of the first logs from any tree in a thicker end and in the thinner end. The measurements were made using a calliper with an accuracy of $\pm 1 \mathrm{~cm}$. The lengths of whole trees were established based on the developed machine assortments registered by the machine. During the works, assortment of $2.5 \mathrm{~m}$ length were made. In addition, five randomly selected and sophisticated stacks were tested using a tape measure, to control metering assortment by the machine computer. These measurements were made using a measuring tape with accuracy of $\pm 1 \mathrm{~cm}$. The volume of individual trees $V s$ was calculated using the Smalian formula (1) (Jaszczak and Magnuski, 2010), where $g_{0}$ is a cross-sectional area at the base of a tree $\left(\mathrm{m}^{2}\right), g_{l}-$ cross sectional area of the thinner end of the tree and $l$ is the length of the tree.

$$
V s=0.5 \cdot\left(g_{0}+g_{l}\right) \cdot l \quad\left(\mathrm{~m}^{3}\right)
$$

The thickness of the total $V$ was defined as the sum of tree volume findings obtained during a working day of the machine operation on the working area. The individual components of the working time were extracted from a recorded movie. 
Mariusz Kormanek, Mariusz Kępa

Table 1.

Basic technical data of harvester and harvester head [information material of Konrad $\mathrm{GmbH}]$

\begin{tabular}{|c|c|c|c|c|c|}
\hline \multicolumn{6}{|c|}{ Harvester HIGHLANDER } \\
\hline Specification & Unit & Value & Specification & Unit & Value \\
\hline Distance of axles & (m) & 4.8 & Engine IVECO & $\begin{array}{c}\text { number of } \\
\text { cylinders }\end{array}$ & 6 \\
\hline $\begin{array}{l}\text { Distance of axles with the } \\
\text { pulled out rear wheels }\end{array}$ & (m) & 6.87 & Power & $(\mathrm{kW})$ & 172 \\
\hline $\begin{array}{l}\text { Max. increase of rear } \\
\text { wheel }\end{array}$ & (m) & 1.35 & Maximum torque & $(\mathrm{Nm})$ & 1020 \\
\hline Width of the machine & (m) & 2.9 & Engine capacity & $\left(\mathrm{dm}^{3}\right)$ & 5.9 \\
\hline $\begin{array}{l}\text { The operating range of the } \\
\text { boom from rotation axis }\end{array}$ & (m) & 10 & $\begin{array}{l}\text { Efficiency/ pressure of } \\
\text { hydraulic pumps } \\
\text { (crane and head) }\end{array}$ & $\begin{array}{c}\left(\mathrm{m}^{3} \cdot \mathrm{h}^{-1}\right) / \\
(\mathrm{MPa})\end{array}$ & $\begin{array}{c}19.2 \\
34\end{array}$ \\
\hline $\begin{array}{l}\text { Total length with an } \\
\text { outstretched crane }\end{array}$ & (m) & 11.7 & $\begin{array}{l}\text { Efficiency/ pressure } \\
\text { hydraulic pumps (chassis) }\end{array}$ & $\begin{array}{c}\left(\mathrm{m}^{3} \cdot \mathrm{h}^{-1}\right) / \\
(\mathrm{MPa})\end{array}$ & $\begin{array}{c}2 \times 18 \\
40\end{array}$ \\
\hline Overall height & (m) & 3.91 & Max. speed & $\left(\mathrm{m} \cdot \mathrm{s}^{-1}\right)$ & 5.56 \\
\hline Turning radius & (m) & 3.5 & Operating weight & (kg) & 20500 \\
\hline \multicolumn{6}{|c|}{ Harvester head Woody 60} \\
\hline Oil flow & $\left(m^{3} \cdot h^{-1}\right)$ & 3.6 & Rotator rotation & $\left({ }^{\circ}\right)$ & $\infty$ \\
\hline working pressure & $(\mathrm{MPa})$ & $30-35$ & Weight (without oil) & (kg) & 1090 \\
\hline Cutting diameter & (m) & 0.60 & Recommended power & $(\mathrm{kW})$ & 88.3 \\
\hline Maximum spacing of ticks & (m) & 0.95 & Feeding speed & $\left(m \cdot s^{-1}\right)$ & $0-4$ \\
\hline Feed force & $(\mathrm{kN})$ & $24-28$ & $\begin{array}{l}\text { The control system of } \\
\text { measurement }\end{array}$ & - & $\begin{array}{l}\text { KONRAD } \\
\text { MCS } 2.0\end{array}$ \\
\hline
\end{tabular}

Inf. materials KONRAD Forsttechnic GmbH

This was done by playing a video in a computer program and the timing of the capture of the individual components, such as:

- technological crossings $\left(T_{11}\right)$, as the time counted from the moment of making the last assortment to reaching and preparing next trees for felling,

- cutting and felling $\left(T_{12}\right)$, as the time from the start of cutting to felling a tree, which was in contact with the ground,

- delimbing and cut to length $\left(T_{13}\right)$, as the time from felling the tree and cutting the last $\log$.

The three phases are combined into one full cycle related to the treatment time per a tree. This was followed by isolating individual components of the operating times of machinery in accordance with the agricultural standard BN-76/9195-01, adapt to the needs of forestry in Poland by the authors of the National Forest Engineering System (Botwin, 1993; Glazar and Wojtkowiak, 2008). It was extracted: 
Analysis of performance...

$\mathrm{T}_{1} \quad$ - effective working time, during which the machine elements are under the load and perform useful work,

$\mathrm{T}_{2} \quad$ - technology down time (determination of trees to be felled),

$\mathrm{T}_{3}$ - daily maintenance time,

$\mathrm{T}_{4}$ - troubleshooting technical time,

$\mathrm{T}_{5} \quad$ - operator's rest time, including physiological needs,

$\mathrm{T}_{6}-$ transport travel time,

$\mathrm{T}_{7} \quad$ - technical operation time of accompanying machines,

$\mathrm{T}_{02}$ - machine operating working time (2),

$$
\mathrm{T}_{02}=\mathrm{T}_{1}+\mathrm{T}_{2}
$$

$\mathrm{T}_{04} \quad$ - working (production) time (3):

$$
\mathrm{T}_{04}=\mathrm{T}_{1}+\mathrm{T}_{2}+\mathrm{T}_{3}+\mathrm{T}_{4}
$$

$\mathrm{T}_{07}$ - total working time, as the sum of separate times during a working day (4),

$$
\mathrm{T}_{07}=\mathrm{T}_{1}+\mathrm{T}_{2}+\mathrm{T}_{3}+\mathrm{T}_{4}+\mathrm{T}_{5}+\mathrm{T}_{6}+\mathrm{T}_{7}
$$

Based on the balance of the working time it was calculated:

- utilization factor of operating time (5):

$$
\mathrm{K}_{02}=\mathrm{T}_{1} \cdot\left(\mathrm{T}_{02}\right)^{-1}
$$

- utilization factor of working time of the shift (6):

$$
\mathrm{K}_{04}=\mathrm{T}_{1} \cdot\left(\mathrm{T}_{04}\right)^{-1}
$$

- utilization rate for general operating time of work shift (7):

$$
\mathrm{K}_{07}=\mathrm{T}_{1} \cdot\left(\mathrm{T}_{07}\right)^{-1}
$$

- auxiliary coefficient characterizing technological certainty (8):

$$
\mathrm{K}_{41}=\mathrm{T}_{1} \cdot\left(\mathrm{T}_{1}+\mathrm{T}_{41}\right)^{-1}
$$

- auxiliary coefficient characterizing technical certainty (9)

Using the balance of the machine working time, the theoretical performance was calculated

- effective performance (10):

- performance during operating working time (11):

$$
\mathrm{W}_{1}=\mathrm{V} \cdot \mathrm{T}_{1}^{-1}\left(\mathrm{~m}^{3} \cdot \mathrm{h}^{-1}\right)
$$

- productivity at machine working time (12):

$$
\mathrm{W}_{02}=\mathrm{V} \cdot \mathrm{T}_{02}^{-1}\left(\mathrm{~m}^{3} \cdot \mathrm{h}^{-1}\right)
$$

- efficiency in the operational time of the shift (13):

$$
\mathrm{W}_{04}=\mathrm{V} \cdot \mathrm{T}_{04}{ }^{-1}\left(\mathrm{~m}^{3} \cdot \mathrm{h}^{-1}\right)
$$$$
\mathrm{W}_{07}=\mathrm{V} \cdot \mathrm{T}_{07}{ }^{-1}\left(\mathrm{~m}^{3} \cdot \mathrm{h}^{-1}\right)
$$ 


\section{Analysis of results}

As a result of measurement and analysis it was identified that the most time-consuming process during processing of one tree was delimbing and cut to length $T_{13}-(54.9 \%)$, (table 2; fig. 2) which was associated with long duration of logs making. Such a long duration of this operation is related to the length of logs, which is connected to the demand of the timber market. Technology crossings $T_{11}$ are also characterized by a high time - consumption (33.2\%). This was due to the fact that the distances between trees were about 5 to $10 \mathrm{~m}$. Such large distances between trees resulted from moderate density, index of trees (0.9) and development phase of the stand (thin stand), as well as the organization of the operator's working time. The shortest time is characterized by the process of felling the tree $T_{12}$ $12 \%$. Normally only one shear cut of tree was performed, then the tree was felled. However, there were some situations in which felling lasted longer (in one case it took 2 min 31 $\mathrm{sec}$ ), which was related to the situation when the tree has been suspended. The operator had to devote more time and a lot more attention in such case, because there was a greater risk of damage to the machine. These three phases consist of the average time of obtaining a single tree, which amounted to $184 \mathrm{~s}$. Figure 3 presents the relationship between the cutting time and the diameter of the tree. As might be expected, the increase in the diameter of the tree caused increase of its cutting time. Values deviating from the trend line resulted from a situation in which trees during felling suspended up (acquisition took place on a difficult surface), as well as there were several cases where quick felling resulted in a cleavage of the timber and operator had to cut such fragment, which increased the time of felling. Effective operating time ( $T_{1}$ ) (fig. 4 ) for 6 hour work shift was 4 h 6 min, which is $67.9 \%$ of the total working time.

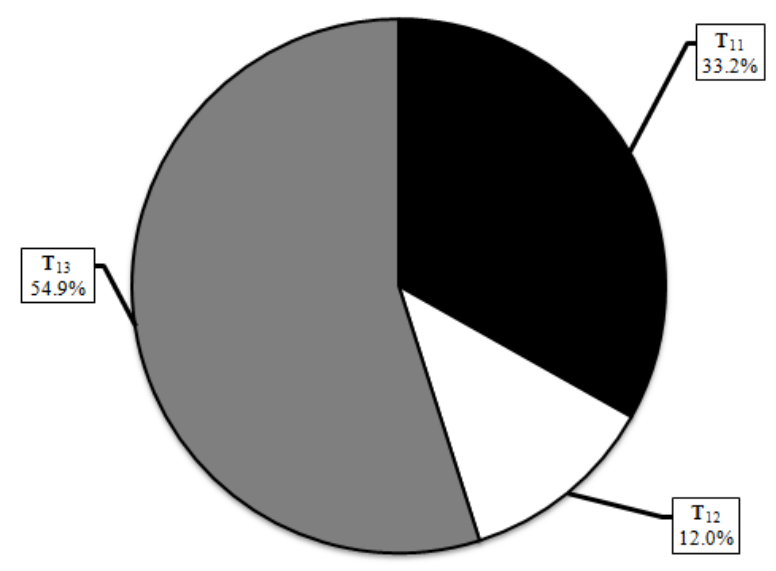

Figure 2. Average percentage share of individual operations during the machining cycle of processing of trees 
Analysis of performance...

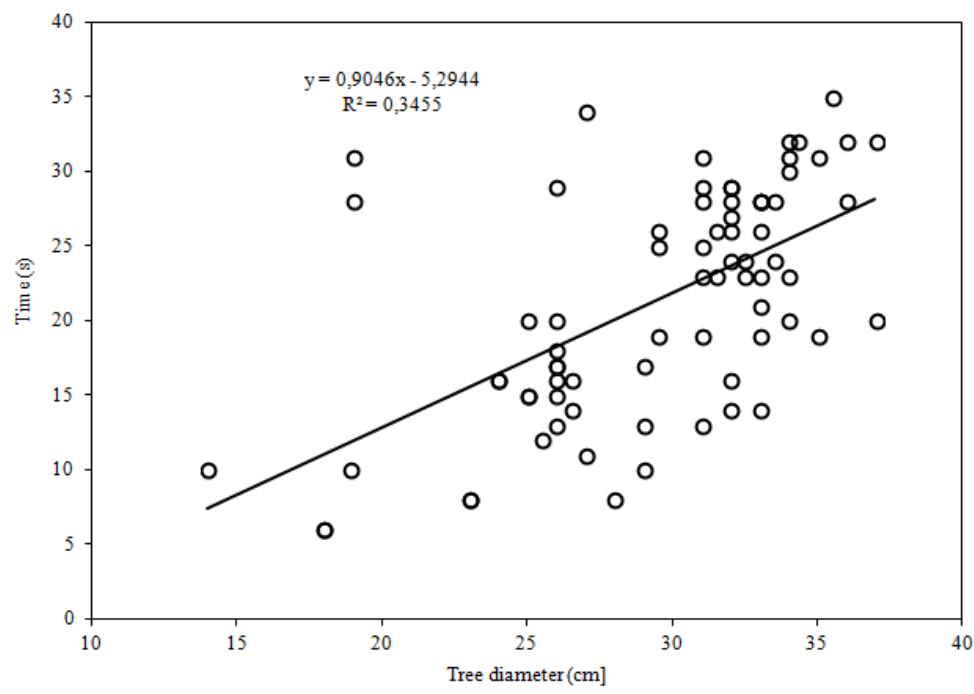

Figure 3. Correlation between duration of felling and tree diameter at the point of cutting by a saw

Table 2.

Components of operating times

\begin{tabular}{lcccccccc}
\hline Parameter & Unit & Result & Parameter & Unit & Result & Parameter & Unit & Result \\
\hline $\mathrm{T}_{01}$ & $(\mathrm{~s})$ & 14664 & $\mathrm{~T}_{2}$ & $(\mathrm{~s})$ & 1056 & $\mathrm{~T}_{6}$ & $(\mathrm{~s})$ & 1080 \\
$\mathrm{~T}_{11}$ & $(\mathrm{~s})$ & 4861 & $\mathrm{~T}_{3}$ & $(\mathrm{~s})$ & 2700 & $\mathrm{~T}_{7}$ & $(\mathrm{~s})$ & 0 \\
$\mathrm{~T}_{12}$ & $(\mathrm{~s})$ & 1753 & $\mathrm{~T}_{4}$ & $(\mathrm{~s})$ & 300 & $\mathrm{~V}_{\mathrm{s}}$ & $\left(\mathrm{m}^{3}\right)$ & 1.017 \\
$\mathrm{~T}_{13}$ & $(\mathrm{~s})$ & 8049 & $\mathrm{~T}_{5}$ & $(\mathrm{~s})$ & 1800 & $\mathrm{~V}$ & $\left(\mathrm{~m}^{3}\right)$ & 76.27 \\
\hline
\end{tabular}

Determination of trees was a downtime technological component $T_{2}$. This activity took the operator $17 \mathrm{~min} 30 \mathrm{sec}$, which is $4.89 \%$ of the work shift. The operator alone marked the trees to be cut down with a marker. The time of daily maintenance $T_{31}$ which is 45 minutes $(12.50 \%)$ is not very satisfactory. This time is associated with starting the machine, heating the engine and achieving the appropriate level of pressure and temperature in the hydraulic system of the harvester and lubricated components. While the machine is running, the operator checks a general condition of the machine (tire pressure, harvester head, oil level in the engine and hydraulic system). During that working day the least timeconsuming activity was the time of troubleshooting of technical faults $T_{42}$, which was 5 minutes (1.39\% in the general work shift). A repair concerned the harvester head and hydraulic hose, which touched the frame while the arm was parting, which in turn interfered with sliding to the end of the telescope and consequently caused incorrect measurement of logs to the programmed length. 


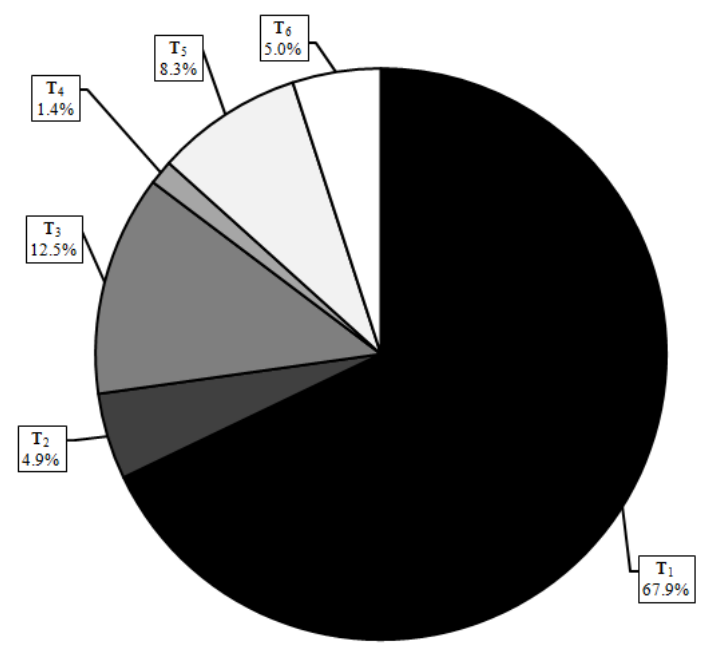

Figure 4. Structure of working time of a shift

Elimination of a fault consisted in replacing a hose with a new one (shorter). The resting time $T_{5}$ in this case was also short. There was only a small part of the overall operating time value $8.33 \%$, equivalent to $30 \mathrm{~min}$. The transport runs $T_{6}$, namely, reaching the location and return was $18 \mathrm{~min} 00 \mathrm{sec}$, which is $5.0 \%$ of the operating time, shift control, which is a very good result. The area, on which the machine worked, was located only about 600 metres from the parking place. In this case parking the Highlander in a young forest was a good solution. Failure to apply this solution would extend the time needed to cover the distance from the base of such a workplace by several times. The technical operation time of the harvester not related to starting and technical operation of working units of the machine was not measured because the machine was purchased as a new one and was less exploited and this time component did not occur. The results obtained from the daily timing of the remaining characteristic combined working times, coefficients and performances were presented in table 3.

Table 3.

Balance of the working day time of machine

\begin{tabular}{lccccc}
\hline Parameter & Unit & Result & Parameter & Unit & Result \\
\hline $\mathrm{T}_{02}$ & $(\mathrm{~s})$ & 15720 & $K_{42}$ & - & 0.98 \\
$\mathrm{~T}_{04}$ & $(\mathrm{~s})$ & 17280 & $W_{1}$ & $\left(\mathrm{~m}^{3} \cdot \mathrm{h}^{-1}\right)$ & 18.74 \\
$\mathrm{~T}_{07}$ & $(\mathrm{~s})$ & 21600 & $W_{02}$ & $\left(\mathrm{~m}^{3} \cdot \mathrm{h}^{-1}\right)$ & 17.45 \\
$\mathrm{~K}_{02}$ & - & 0.93 & $W_{04}$ & $\left(\mathrm{~m}^{3} \cdot \mathrm{h}^{-1}\right)$ & 15.89 \\
$\mathrm{~K}_{04}$ & - & 0.85 & $W_{07}$ & $\left(\mathrm{~m}^{3} \cdot \mathrm{h}^{-1}\right)$ & 12.71 \\
$\mathrm{~K}_{07}$ & - & 0.68 & & & \\
\hline
\end{tabular}


Analysis of performance...

The utilization factor of the operating time $\mathrm{K}_{02}$ was high and amounted to 0.93 . The time lost on technical downtimes (appointment of trees) was low. A low level of the utilization factor of the working time $\mathrm{K}_{04}$ equal to 0.85 was influenced mainly by the daily maintenance time $T_{3}$, which for only 6 hour working day accounted for a large percentage. The utilization rate for general operating time of work $K_{07}$ was relatively low and it was only 0.68 and it was due to the participation of other times in relation to a short working day. The rate of technical certainty $K_{42}$ was high 0.98 and it was related to no serious faults of the Highlander harvester $T_{4}$, which resulted from the fact that the machine was purchased as a new one and was little exploited. Effective capacity of the Highlander harvester $W_{1}$ was at $18.74 \mathrm{~m}^{3} \cdot \mathrm{h}^{-1}$ and it was similar to Valmet 901.3 thinning harvester (engine power 140 $\mathrm{kW})$. It worked on a similar area in late thinning, with forestation rate of 0.8 and the average thickness of the trees of 0.65 . Theoretical efficiency $\left(W_{1}\right)$ for Valmet was at 17.60 $\mathrm{m}^{3} \cdot \mathrm{h}^{-1}$. Efficiency in the overall machine working day for Highlander was $12.71 \mathrm{~m}^{3} \cdot \mathrm{h}^{-1}$, and it was similar to Valmet $12.32 \mathrm{~m}^{3} \cdot \mathrm{h}^{-1}$ and to Ponsse Ergo (Sadowski et al., 2014), which performed the work in acquisition of the pine tree in thinning class III (52 years old trees), efficiency in the overall machine working day $W_{07}$ was $11.25 \mathrm{~m}^{3} \cdot \mathrm{h}^{-1}$. Analysis of the obtained results proves that the Highlander type harvester efficiency was comparable to the machines of other producers. Possible improvements to the effective time of the Highlander machine can be made with extending the work shift and best shift work. Assessing the operation of the machine type Highlander in conditions of studies can indicate a number of its advantages. The machine has excellent traction chassis properties which in the course of research checked well in difficult conditions, the sticky terrain with low load-bearing capacity. The harvester operator has a very good field of vision upwards, which is very important during harvesting in order to determine the direction of gravity and tree felling direction, as in the case of a harvester Highlander vertical angle of view of more than 120 degrees. The harvester cabin is reinforced by a steel outer frame, and in addition the windscreen is hardened and resistant to impact, which protects the operator from uncontrolled collapse of e.g. a tree branch on the machine. In case of shift work and poor visibility (after dark) external lighting elements perform their role very well.

\section{Conclusions}

Based on the harvester working operation timing it can be concluded that:

1. Arrangement of the harvester working time could be better. This is indicated by a low coefficient of general application of the operating time of a shift, which is only 0.68. Extension of shift up to 8 hours would be beneficial for improving this parameter.

2. Time of daily maintenance, which is 45 minutes $(12.50 \%)$, is long. The percentage of the working shift time could be reduced through the application of extension to two or three shift work system.

3. Performance in general, exploitation machine working time which was $12.71 \mathrm{~m}^{3} \cdot \mathrm{h}^{-1}$ does not differ from the performance of other machines working in similar conditions. It is possible to increase the productivity primarily by lengthening the working day, as well as improving training of an operator.

4. The area where the machine worked was very hard, and in places very slushy. During operation advantages of machine chassis became evident. The machine has a number of 
advantages associated with the ergonomics and comfort of work arrangements that facilitate work in the forest.

\section{References}

Botwin, M. (1993). Podstawy użytkowania maszyn leśnych. Wydawnictwo SGGW. Warszawa. ISBN 83-00-02777-7.

Bodył, M. (2014). Nadleśnictwo jak w Szwecji. Drwal, 7, 5-9.

Glazar, K., Wojtkowiak, R. (2008). Koszty pracy maszyn leśnych. Przemysłowy Instytut Maszyn Rolniczych. Poznań. ISBN 978-83-927505-2-9.

Inf. materials of State Forests (2010): Technika Rolnicza Ogrodnicza i Leśna, 6, 4-7.

Jaszczak, R., Magnuski, K. (2010). Urządzanie lasu. Uniwersytet Przyrodniczy w Poznaniu. ISBN 978-83-7160-569-7.

Maksymiak, M., Grieger, A. (2008). Analiza wydajności pracy przy maszynowym pozyskaniu drewna na przykładzie harwestera Valmet 901.3 i forwardera Valmet 840.2. Inżynieria Rolnicza, 1(99), 273-281.

Moskalik, T. (2004). Model maszynowego pozyskania drewna w zrównoważonym leśnictwie polskim. Wydawnictwo SGGW Warszawa. ISBN 83-7244-491-9.

Sadowski, J., Moskalik, T., Zastocki, D. (2014). Efektywność pozyskania drewna harwesterem PONSSE Ergo w wybranych drzewostanach. Studia $i$ Materiały CEPL $w$ Rogowie. 39/2B, 126-132.

Skarżyński, J., Brzózko, J. (2010). Harwestery do pozyskania drewna stosowane w polskich lasach cz.1. Charakterystyka ogólna-nośniki. Technika Rolnicza Ogrodnicza i Leśna, 6, 8-2.

Żabierek, R. (2013). Analiza stanu technicznego i kosztów eksploatacji wielooperacyjnych maszyn leśnych oraz forwarderów pracujących w polskich lasach. Uniwersytet Przyrodniczy w Poznaniu. Maszynopis. Praca doktorska.

Inf. materials KONRAD Forsttechnic GmbH. Obtained from: http://www.forsttechnik.at/en.

Inf. materials Fao Far. Obtained from: http://www.faofar.pl.

Inf. materials Belarus. Obtained from: http://lupus-wilk.com.pl.

\section{ANALIZA WYDAJNOŚCI HARWESTERA HIGHLANDER PRZY MASZYNOWYM POZYSKIWANIU DREWNA}

Streszczenie. W artykule przedstawiono analizę wydajności harwestera Highlander firmy Konrad Forsttechnic GmbH, przy maszynowym pozyskiwaniu drewna. Analizę wykonano w oparciu o chronometraż dnia roboczego, co posłużyło również do oceny organizacji pracy oraz funkcjonalności badanego harwestera. Badania przeprowadzono na terenie Nadleśnictwa Międzylesie, Leśnictwo Nowa Wieś na typie siedliskowym lasu las mieszany górski świeży (LMGśw), gdzie harwester pozyskiwał drewno świerkowe. Chronometraż wykonano w oparciu o rejestrację czasu eksploatacji harwestera przy pomocy kamery wideo oraz pomiarów pozyskanego sortymentu. Na podstawie uzyskanych wyników stwierdzono, że organizacja pracy maszyny nie była najlepsza. Jednozmianowy system pracy oraz krótki czas trwania zmiany spowodował, że efektywny czas pracy wynosił tylko $67,9 \%$ czasu zmiany tj. ok 4 h. Pomimo wysokiej wydajności efektywnej harwestera, która wyniosła $18,7 \mathrm{~m}^{3} \cdot \mathrm{h}^{-1}$, to uzyskana przez niego wydajność eksploatacyjna była niska i wyniosła $12,7 \mathrm{~m}^{3} \cdot \mathrm{h}^{-1}$.

Słowa kluczowe: harwester, pozyskiwanie drewna, wydajność harwestera 